\title{
BOARD CHARACTERISTICS AND INDUSTRY SPECIALIST AUDITOR : THE MODERATING ROLE OF CONCENTRATED OWNERSHIP
}

\author{
Nishtiman Hahsim Mohammed
}

Faculty of Business and Economic, University of Duhok, Duhok, Kurdistan Region - Iraq

\begin{abstract}
This study illustrates the impact of concentrated ownership on the monitoring role of board of directors in term of high quality audit proxy by industry specialist auditor. The integration of agency theory and resource dependency theory reflects that board has different incentives and abilities to monitor management. The analyses of Turkish listed firms indicates that board characteristic complement high quality audit when ownership concentration at low levels. When ownership concentration is at high level, this is not the case- proposing that there is substitution influence between concentrated ownership and board characteristics in term of the demand for high quality audit.

KEYWORDS : Board characteristics, industry specialist auditor, concentrated ownership in Turkey firms.
\end{abstract}

\section{INTRODUCTION}

Is board monitoring role equally important in all firms, independent of their ownership structure? researcher report that there is no one best way exit. For instance, based on institutional analysis and strategic governance the effectiveness of corporate governance depend on environment characteristics and interdependent organizations. Corporate governance has been defined as a system with interrelated process and practise with institutional complementariness, where governance practise will be more effective in particular combination. Moreover, those combined mechanism of corporate governance lead to various patterns of it (Aguilera, Filatotchev, Gospel, \& Jackson, 2008). The monitoring effectiveness depend on a bundle of corporate governance mechanisms instead of any single one. Consequently, studies investigating a particular mechanism of corporate governance regularly address vast connection between different corporate governance mechanisms and neglect their substitution and complementary influence on various firm outcome. Shareholder depend on different mechanisms of corporate governance in order to supervising their agents for instance, external auditor (Watts \& Zimmerman, 1990), direct shareholder supervision, board control (Renee B Adams, Gray, \& Nowland, 2010). The main issue of this study is to examine the extent to which

Academic Journal of Nawroz University

(AJNU) Volume 7, No 3 (2018).

Received 23 Feb 2018;

Regular research paper : Published 20 June 2018

Corresponding author's e-mail : nishtimanmohammed87@gmail.com

Copyright (C2018 Nishtiman Hahsim Mohammed.

This is an open access article distributed under the Creative

Commons Attribution License. board depend on external audit as mechanism of monitoring contingent on concentrated ownership. Previous literature by Tuggle, Sirmon, Reutzel, and Bierman (2010) report that board monitoring effectiveness not only depend on directors incentive but also on their ability to do it. Consistently, shareholders ability to monitor management behavior rely on their incentive (the magnitude of shareholders investment) and ability (Kaplan \& Minton, 1994). This paper view consistent with the argument that corporate governance effectiveness contingent on ownership structure. More specifically, this paper concentrates on board monitoring function measured by clients demand for high quality audit (industry specialist auditor) and examine the moderate role of concentrated ownership on the relationship between board characteristics and audit quality. To empirically examine whether board characteristics considers an important matter, one trend of studies have examined the influence of board characteristics on firm performance, but the result is inconsistent and mixed (Finkelstein \& Hambrick, 1996a). Another trend of studies proposed that there is direct relationship between board monitoring function and board strategic behavior and indirect relationship with firm performance (Deutsch, 2005). Furthermore, a multitude of exogenous and endogenous variables beyond board characteristics impact on firm performance (Kosnik, 1987). Therefore, instead of evaluate the effectiveness of board monitoring by observing the performance of the firms, a more relevant evaluation might be achieved by examining board strategic decision to align the interests between principle and agent (Sundaramurthy, 1996). The decision of high quality auditor engagement is one of the strategic behavior of board of directors, this paper examine extent to which 
board behavior contingent on ownership structure. Based on the integration of agency-dependency theory board of director has distinct incentive and ability to monitor management. This study propose that board characteristics substitute with ownership structure when it come in monitoring function. it suggests that firms characterized with dispersed ownership, board monitoring function will be more effective. This is due to the problem of coordination between shareholders, thus shareholders lack of incentives and abilities to oversight management directly (Davies, 2000). In contrast, concentrated ownership directly monitor management behavior as a consequence of their incentive and abilities (Bohinc \& Bainbridge, 2001). External audit represents as a significant mechanism to improve shareholder wealth. External auditor attests that all investors are treated equally and the financial reports are in conformity with contractual agreement. External auditor look at corporate board as it is clients even though board of directors review audit fees including audit scope and plan (Carcello, Hermanson, Neal, \& Riley, 2002). Moreover, the OECD Principles of corporate governance (2004) reports that corporate board should work in the best interests of stakeholders, act on a fully informed basis, with due diligence and care. In many countries, aforementioned fiduciary duties take the form of statutory obligations, and some of them for instance, United State US and Canada take the form of extensive law (Desender, Aguilera, Crespi-Cladera, \& GarciaCestona, 2009). Theoretical and empirical contributions has been achieved by this study. In term of theoretical contribution, This study provides greater understanding about the impact of ownership structure on the mechanism of corporate governance. Aguilera and Jackson (2003) report the importance of environmentorganization interdependence on the effectiveness of corporate governance and the need to move behind "under-contextualized" logics. Studies examined the effectiveness of corporate governance mechanism got mixed results and the main reason beyond that might be the neglect of different pattern of corporate governance in various organizational settings. This study is based on this suggests that the relationship between various corporate governance characteristics is contingent on ownership structure of the firms. More specifically, this study develop the conceptual framework of agency theory through integrate agency-dependency theory to analysis board strategic in terms of monitoring management behaviors, depend on ownership structure. Whereas, agency theory have not addressed that boards possess distinctive incentive and ability to conduct the monitoring function, this study propose that board has heterogeneous incentives and abilities. Consequently, board of directors differ in their monitoring function. This study framework reflects that to get clear understanding about board incentive and ability to monitor management must control for ownership structure because the interaction between those variables leads to various pattern of board monitoring. From an empirical phase, by reviewing Continental European environment, this study examine external soundness of corporate governance studies addressed in the Turkey context. Moreover, because this study examine the moderate role of concentrated ownership, this study result add to the comparative literature in corporate governance through display how different patterns of corporate governance practices related to ownership structure.

\section{Theoretical Framework and Hypotheses}

Corporate governance considers an interrelated mechanisms in which some practices will be effective and relevant only in particular combinations, leading to various arrangements of corporate governance (Aguilera et al., 2008). In this regard, this study adopt a contingency approach to investigate how the ownership structure impacts board behavior towards the selection of audit quality. This study points of view based on the integrated of both of agency theory and resource dependence theory views and expand agency theory propositions by concentrating on how ownership structure influence not only on clients incentive to demand high quality audit, but also their ability to do so. Whereas, clients incentive is underlined by agency theory, the clients ability to demand strong monitoring mechanism stems from resource dependency theory (Hillman, Cannella, \& Paetzold, 2000). Furthermore, this study argue that the monitoring role of board of directors rely on the incentives and abilities of various structures of firm ownership to oversight management directly (instead of depend on the corporate board). This study proposes that ownership structure of the firm is crucial in analyzing the monitoring function, as their combination leads to various patterns of board demand for audit quality. Previous studies concentrated on clients demand for audit quality. Most of the previous literature on clients demand for high audit quality is based on a theoretical model, that there is complementary or substitution influence between corporate governance and audit quality (Gacar, 2016; Karaibrahimoglu, 2013). Another stream of studies examine the relationship between corporate governance quality and audit quality (Zaman, Hudaib, \& Haniffa, 2011). Nevertheless, conceptual link on the mechanisms address aforementioned relationship-specifically when it focus on board impacts on clients demand for high audit quality. In order to build the study model and evaluate the adopted contingency approaches, in the first step, the relationship between board characteristics and audit quality have been addressed. Secondly, the study examines the strength of the relationship between board 
characteristics and audit quality contingent on the shows in Figure 1. ownership structure. The conceptual model of the study

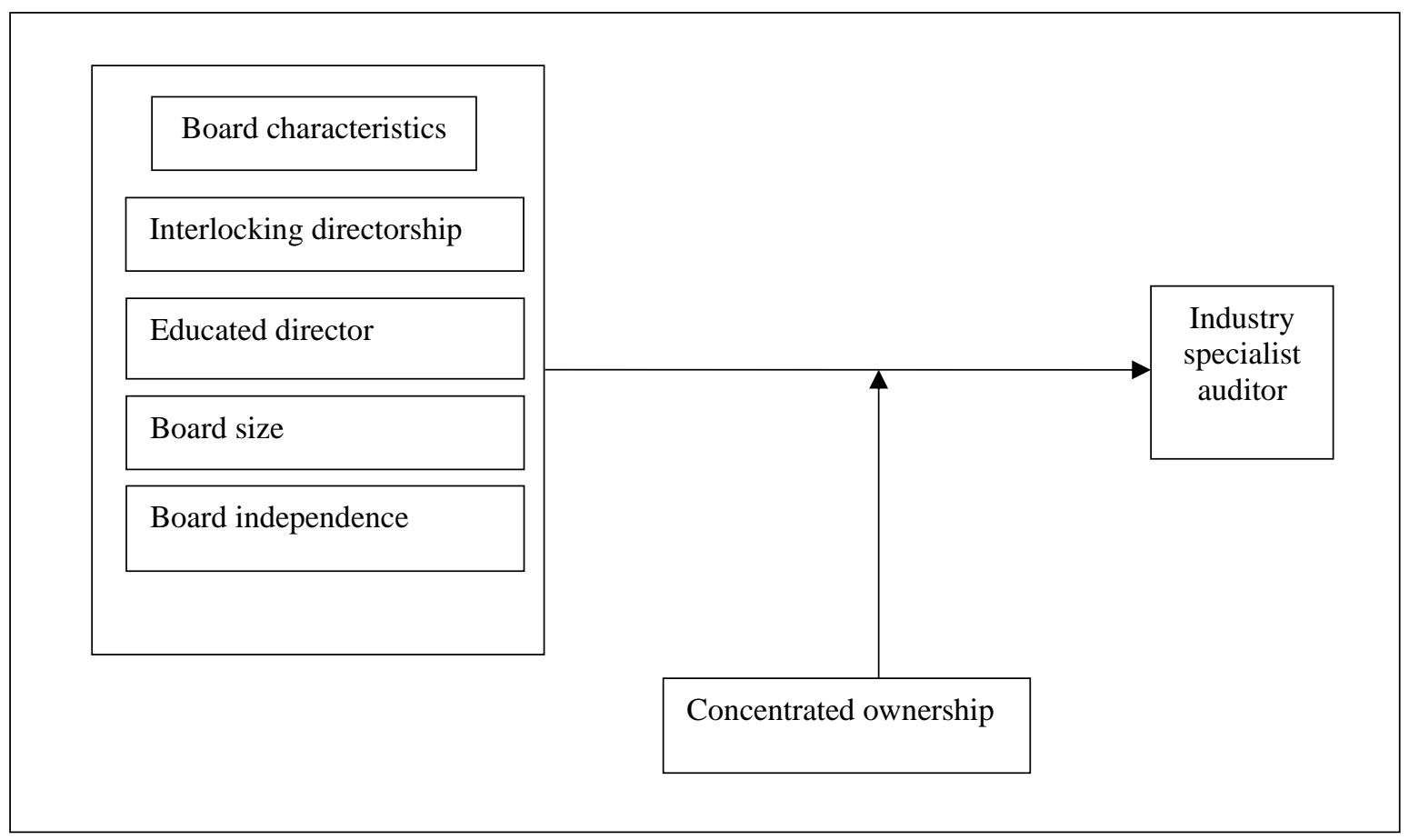

Fig 1. The relationship between board characteristics, concentrated ownership, and industry specialist auditor

2.1 Interlocking directorship and industry specialist auditor

Interlocking directorships indicates to those directors who occupy more than one boards of director. Based on resource dependency theory, interlocking directors considers as human capital because they play significant advisory role. Interlocking directorship gets strong qualification and capabilities to make effective decisions as a consequence of their experience through working in more than one board of directors (Harris \& Shimizu, 2004). Interlocking directors skills, knowledge and expertise help firms to improve management monitoring function and thus enhance their financial reporting quality (Hashim \& Rahman, 2011). Previous empirical studies suggest that interlocking directorship improves earning quality and little is known in terms of clients demand for high audit quality, accordingly, it is infer that interlocking directorship increase clients demand for high audit quality. In contrast, previous literature by Courtney and Jubb (2005), Davison, Stening, and Wai (1984a) and Seabright, Levinthal, and Fichman (1992) indicates that interlocking directorship have negative influence on board monitoring mechanism. This indicates that interlock directorship improve the relationship between the clients and audit firms. So, interlock organizations are more likely to hire the same auditor for longer time. Thus, this study suggests that cognitive diversity proxy by interlocking directorship is related to audit quality and it propose the following hypothesis : $\mathrm{H} 1$ : There is a relationship between interlocking directorship and audit quality.

2.2 Education Level and industry specialist auditor

Board of directors with educational background provide a valuable assets to the firms. Directors with higher education background for instance, Master and $\mathrm{PhD}$ degree will improve the value of human capital (Plian, 1995) or having strong cognitive capability, higher ability for decision processing, and propensity to innovation which equip them with an effective solution for decision making function (Bantel \& Jackson, 1989). Therefore, educated directors are less likely to experience turnover as their turnover portray a loss to the firms (Ou-Yan \& Shuang-shii, 2007) as educated directors serves some functional background for instance problem definition, strategic choices and information procession (Datta \& Rajagopalan, 1998). In contrast, previous studies report adverse relationship between educated directors and board monitoring mechanisms in term of industry specialist auditor (Cheng \& Leung, 2012a). The logic interpretation is educated director are less conservative in making strategic decisions and the have strong incentive to engage in management earning. According to the mixed results of previous literature, the study hypothesis is

H2: There is a relationship between educated directors and audit quality. 


\subsection{Board size and industry specialist auditor}

Previous studies addressed the influence of board size (number of directors occupy corporate board) on the effectiveness of corporate governance in firms (Beiner, Drobetz, Schmid, \& Zimmermann, 2004). Nonetheless, In regards to board size, Jensen (1993) and Mustafa, CheAhmad, Chandren, \& Sitraselvi (2017) reported that small board might be more effective than large board of directors as a result of free riding and coordination problems. They suggested that the appropriate size of corporate board should be not greater than 8 to 9 directors. On the other side, some scholars argued that smaller board lack of necessary management capabilities. Based on resource dependency propositions, scholars have suggested that large board of directors have greater collective information consequently this will influence positively to improve firm performance. Furthermore, previous studies reported that larger board possess more specialists from different areas and might provide better advice and counsel to the chief executive officer (Dalton, Daily, Johnson, \& Ellstrand, 1999). However, the coordination problem between board member might overweigh the advantages behind having larger corporate boards (Dalton et al., 1999; Guest, 2009). This indicates that there is inconsistency in the results of previous studies regarding the relationship between board size and audit quality, therefore requires further investigation. Based on this, the study hypothesis is :

H3 : There is a relationship between board size and audit quality.

2.4 Board Independence and industry specialist auditor Board independence represents as one of the important characteristics that improve the effectiveness of board of directors. Agency theory assume that non-executive directors are more likely to enhance board monitoring role (Jensen \& Meckling, 1979; Shleifer \& Vishny, 1997). Organizational studies reported that independent directors acts to improve and protect their legitimacy, particularly in the investor community (Filatotchev, Lien, \& Piesse, 2005). This align with the propositions that nonexecutive directors play significant role to improve management monitoring function (Chancharat, Krishnamurti, \& Tian, 2012). In addition, they provide balance in decision making particularly, stakeholders protections (Nugroho \& Eko, 2012). Furthermore, studies suggested to occupy more independent directors to protect shareholders from opportunistic activities of executive directors (Jensen \& Meckling, 1979). Therefore, non-executive directors are essential characteristics to improve board effectives and efficiency (Haniffa \& Hudaib, 2006). Fama and Jensen (1983) reported that independent directors possess valuable expertise and they provide wide connection to the firm, that influence positively to improve board monitoring effectiveness. On the other hand, Lee et al. (2004) document a negative relationship between an independent board of directors and frequency of auditor resignation. This is because board independence has a crucial role in mitigating the negative impacts inherent in auditor resignation. Based on the inconsistency of previous studies results, the study hypothesis is :

$\mathrm{H} 4$ : There is a relationship between board size and audit quality.

2.5 Board characteristics and industry specialist auditor : contingent on concentrated ownership

Board monitoring function has been studies extensively be corporate governance studies (Adams \& Ferreira, 2009), specifically as it relates to the impact of board characteristics (e.g. interlocking directorship, educated directors, board size and board independence) (Ararat, Süel, Aytekin, \& Alkan, 2014; Finkelstein \& Hambrick, 1996b), there is inconsistency in the results of previous studies on those agency theoretic suggestions in respect to board monitoring function. Dalton, Hitt, Certo, and Dalton (2007) a review of audit quality literature do not provide support for this relationship. Aguilera and Jackson (2003) reports that critics of the agency theory viewpoint have notice its "under-contextualized" nature and, therefore, its inability to clarify adequately the variety of governance provisions across diverse contexts. The best combination of governance mechanisms should be considered as a bundle where the effectiveness of one mechanism contingent on the effectiveness of the others (Rediker \& Seth, 1995). Concentrated ownership is an internal governance mechanism that could range from numerous small shareholders and a sole majority owner. This study argue that there is complementary or substitution impact between concentrated ownership and the corporate board in regards to monitoring function. Specifically, an integration of agency theory and resource dependence theory indicates that board of directors have typical incentive and ability to demand high audit quality (Hillman et al., 2000). In particular, they suggest that, rather than assuming that boards of directors with an equal number of independent directors will assure the same monitoring effectiveness, it is assume that those independent directors could possess unequal incentive and ability to monitor. Based on this, the study suggests that the positive influence of board independence on audit quality is contingent on the firm concentrated ownership. Therefore, the study propose the following hypotheses:

H5 : Concentrated ownership moderate the relationship between board characteristics and industry specialist auditor.

H5a : Concentrated ownership moderate the relationship between interlocking directors' and industry specialist auditor.

$\mathrm{H} 5 \mathrm{~b}$ : Concentrated ownership moderate the relationship between educated directors' and industry specialist 
auditor.

$\mathrm{H} 5 \mathrm{c}$ : Concentrated ownership moderate the relationship between board size and industry specialist auditor.

$\mathrm{H} 5 \mathrm{~d}$ : Concentrated ownership moderate the relationship between board independence and industry specialist auditor.

3. RESEARCH METHOD

3.1 Population and sampling

Secondary data has been utilized from 2011 to 2015. This could assist to examines the regulatory changes in 2012 . This study sample exclude financial institutions because these kind of institution implement different corporate governance code than non-financial firms (Maury, 2006). Bursa Istanbul (BIST) shows that there are about 411 listed firm in the end of 2015 and table 1 explain sample selection process.

Table (1) : Procedures of sample selection

\begin{tabular}{l|l|}
\hline Firms listed in Borsa Istanbul Webpage in 2015 & $\mathbf{4 1 1}$ \\
\hline Less : financial institution and holding & 142 \\
Less : firms with missing corporate governance information & 15 \\
Less : firms with missing directors profiles & 70 \\
Less : firms with missing interlocking directors information & 38 \\
Final sample observations & 146
\end{tabular}

\subsection{Research model and measurement}

The first model of this study investigate the relationship between board characteristics measured by Interlocking directorship, education level, board size and board independence and control variables and audit quality measured by industry specialist auditor. This might help to meet this study objective and answer it is questions. Therefore, developed hypotheses of this study are examined using the following model :

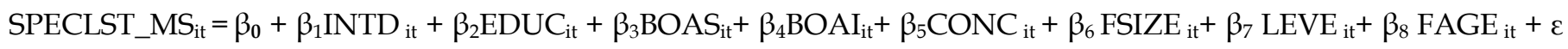

it.

Where :

For each firm (i) and each year (t)

\begin{tabular}{lll} 
SPECLST_MS $_{\text {it }}=$ & \multicolumn{2}{l}{ Industry specialist auditor } \\
INTD & $=$ & Interlocking directorship \\
UDUC & $=$ & Education level \\
BOAS & $=$ & Board size \\
BOAI & $=$ & Board Independence \\
FSIZE & $=$ & Firm size \\
LEVE & $=$ & Leverage \\
FAGE & $=$ & Firm age
\end{tabular}

$\varepsilon_{\text {it }} \quad \quad=\quad$ Error term supposed to be normally scattered with constant differences

Model 2 investigates the moderating influence of board independence and control variables with audit concentrated ownership in the relationship between quality. The structure equation of the regression is as interlocking directorship, education level, board size and follows :

SPECLST_MS ${ }_{\text {it }}=\quad \beta_{0}+\beta_{1}$ INTD $_{\text {it }}+\beta_{2}$ EDUC $_{\text {it }}+\beta_{3}$ BOAS $_{\text {it }}+\beta_{4}$ BOAI $_{i t}+\beta_{5}$ CONC $_{\text {it }}+\beta_{6}$ CONC $^{*}$ INTD $_{\text {it }}+\beta_{7}$ $\mathrm{CONC}^{*} \mathrm{EDUC}_{\mathrm{it}}+\beta_{8} \mathrm{CONC}^{*} \mathrm{BSIZE}_{\mathrm{it}}+\beta_{9} \mathrm{CONC}^{*} \mathrm{BINDE}_{\mathrm{it}}+\beta_{10}$ FSIZE $_{\mathrm{it}}+\beta_{11} \mathrm{LEVE}_{\mathrm{it}}+\beta_{12}$ FAGE $_{\text {it }}$ 
Where :

$$
+\varepsilon_{\text {it. }}
$$

For each firm (i) and each year ( $t$ )

\begin{tabular}{|c|c|}
\hline SPECLST_MS $_{\text {it }}=$ & Industry specialist auditor \\
\hline INTD & Interlocking directorship \\
\hline UDUC & Directors level of educatio \\
\hline BOAS & Board size \\
\hline BOAI & Board independence \\
\hline CONC & Concentrated ownership \\
\hline FSIZE & Firm size \\
\hline LEVE & Leverage \\
\hline FAGE & Firm age \\
\hline
\end{tabular}

$\varepsilon_{\text {it }} \quad=\quad$ Error term supposed to be normally scattered with constant differences

3.3 Measurement of Variables and Descriptive Statistics industry total assets audited by particular audit firm Table 2 shows the number of observation, mean, relative to the total assets for all firms in that particular standard deviation, $\min$ and $\max$ for SPECLST_MS, industry. Table 2 shows the average of SPECLST_MS is INTD, EDUC, BSIZE and BINDE and control variables about 0.176 ( a standard deviation of 0.234) with a ranged (FSIZE, LEVE and FAGE). Consistently with previous from a minimum of 0.000 to a maximum of 0.984 .

literature by Craswell, Francis, and Taylor (1995) this study defines industry market share as the fraction of

Table (2) : Descriptive Statistics

\begin{tabular}{|c|c|c|c|c|c|}
\hline Variable & Observations & Mean & $\begin{array}{c}\text { Standard } \\
\text { deviation }\end{array}$ & Minim & Maxim \\
\hline SPECLST & 724 & 0.176 & 0.234 & 0.000 & 0.984 \\
\hline INTD & 724 & 3.875 & 2.673 & 0 & 8 \\
\hline EDUC & 724 & 2.303 & 1.849 & 0 & 12 \\
\hline BOAS & 724 & 6.783 & 2.128 & 0 & 1 \\
\hline BINDE & 724 & 1.812 & 0.909 & 0 & 2.608 \\
\hline CONC & 724 & - & - & 1.433 & 1.707 \\
\hline FSIZE & 724 & 1.904 & 1.781 & 0 & 80 \\
\hline LEVE & 724 & 0.481 & 0.279 & 1 & \\
\hline FAGE & 724 & 33.825 & 15.856 & & \\
\hline
\end{tabular}

The percentage of interlocking directors to the total education level. The mean number of ( PhD and Master number of directors work in the board of directors is used to measure interlocking directorship. The average number of interlocking directorship is about 3.875 with a standard deviation of 2.673 with a ranged from a minimum of 0 and maximum of 12 directors work in more than one directorship. The percentage of educated directors to total number of director is used to measure degree) is about 2.303 with a minimum of 0 to 8 and a standard deviation of 1.849. The average size of corporate boards is about $6.783 \sim 7$. Corporate board in Turkey is smaller than United Kingdom (UK) and United State (US) which is about 8.01 and 12.48 respectively (Peasnell, Pope, \& Young, 2005). The meran number of independent directors is about 1.812 with standard 
deviation of 0.909 . and a range from of 0 to 5. free from multicollinearity this is because VIF results for Concentrated ownership is measured using binary measurement. Table 3 shows the correlation between the study variables. The values of the correlation between all variables is less than 0.80 . This indicates that there is no multicollinearity problems present between the study variables. The value of Variance influence Factor (VIF) and tolerance factor (1/VIF) also indicates that the data independent and control variables are less than 5 as proposed by (Hair, Black, Babin, \& Anderson, 2010). The correlation finding reflects that there are positive correlation present between INTD, BSIZE, FSIZE, and FAGE expect of CONC that possess a negative correlation with SPECLST_MS. Whereas, EDUC, BINDE and LEVE are not correlated with SPECLST_MS.

Table (3) : Pearson correlation $(\mathrm{N}=724)$

\begin{tabular}{c|c|c|c|c|c|c|c|c|c|c}
\hline & $\begin{array}{c}\text { SPECLS } \\
\text { T_MS }\end{array}$ & INTD & EDUC & BSIZE & BINDE & CONC & FSIZE & LEVE & FAGE & VIF \\
\hline SPESLST_M & 1.000 & & & & & & & & \\
S & & & & & & & & \\
INTD & 0.263 & 1.000 & & & & & & & & 1.25 \\
EDUC & 0.051 & 0.109 & 1.000 & & & & & & & 1.12 \\
BSIZE & 0.144 & 0.385 & 0.002 & 1.0000 & & & & & & 1.40 \\
BINDE & 0.061 & 0.091 & -0.020 & 0.330 & 1.000 & & & & & 1.16 \\
CONC & -0.210 & -0.071 & -0.081 & -0.031 & -0.028 & 1.000 & & & & 1.11 \\
FSIZE & 0.469 & 0.277 & 0.012 & 0.296 & 0.209 & -0.225 & 1.000 & & & 1.25 \\
LEVE & 0.054 & 0.012 & -0.033 & 0.035 & 0.042 & -0.136 & 0.245 & 1.0000 & & 1.09 \\
FAGE & 0.279 & 0.064 & -0.144 & 0.214 & 0.129 & 0.150 & 0.101 & -0.0662 & 1.0000 & 1.15 \\
\hline
\end{tabular}

Notes : Two-tailed, bold $=$ correlation are significant at $\mathrm{P}<0.05 .{ }^{*} \mathrm{FSIZE}$ is natural log of total assets. ${ }^{* *} \mathrm{FAGE}$ is natural log of firm age.

\subsection{Tests for Random and Fixed effects Regression}

This study depends on Hausman test in order to select between fixed and random effects. This is because Huasman test examine whether there is any correlation between (Ui) and the regressors (Greene, 2003). If pro > chi2 is $<0.05$ (i.e., significant) the fixed effect model is used (Greene, 1997). The finding of Husman test displays probability more than 0.05 therefore, the null hypothesis has been rejected and random effects is more appropriate for estimation purpose for the study. Consequence, the individual error component is not correlated with regression variables, then OLS estimator is consistent. As a result of the existence Autocorrelation and heteroscedasticity as characterized in panel data, this study uses Feasible Generalized Least Square (FGLS) to correct for this problem as (Wooldridge. J. M., 2002) proposed.

\subsection{Results of the Models}

The reported Wald Chi 2 utilising FGLS for Model1 and Model2 are about (327.92 and 340.14) respectively (Table 3.4). This displays that independent variables show about $327 \%$ and $340 \%$ of the deviation in the dependent variable. This suggest that, around $327 \%$ and $340 \%$ of the variance in the industry specialist auditor is explained by
INTD, EDUC and BSIZE. The findings of this study are align with that of agency-dependency suggestions, that board characteristics possess significant impact on clients demand for high audit quality in terms of SPECLST_MS. In particular, INTD possess significant influence on board monitoring mechanism. The finding for INTD is highly significant at $1 \%$ level of significance with Pvalue of (0.000) for Model1. Besides, the degree of influence on SPECLST_MS is about (0.68) and t-value of 4.46. This shows that any increase in INTD by one unite will leads to increase about 0.68 on clients demand for high audit quality. The influence of educated directors on SPECLST_MS in contrast to another analytical results on Table 3.4 shows that educated directors possess greater influence on clients demand for high audit quality. The same argument is proposed by (Mustafa et al., 2017).

The finding in Table 3.4 reflects that education level of board of directors effects positively to improve clients demand for high audit quality with P-value of (0.072) and $t$-value of (1.80). this shows that for every one qualified directors with ( $\mathrm{PhD}$ and master degree), clients demand for high audit quality will increase by 0.12 . 
Table (3.4) : Regression Models (FGLS)

\begin{tabular}{|c|c|c|c|c|c|c|c|c|}
\hline \multirow[b]{2}{*}{ Item } & \multicolumn{4}{|c|}{ Model 1} & \multicolumn{4}{|c|}{ Model 2} \\
\hline & & 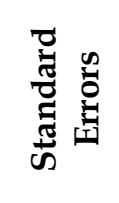 & $\begin{array}{l}\frac{0}{3} \\
\frac{\pi}{2} \\
\frac{1}{1}\end{array}$ & $\begin{array}{l}0 \\
\frac{0}{\pi} \\
\\
\vdots \\
2\end{array}$ & 莡 & 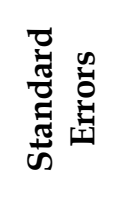 & $\frac{\frac{0}{J}}{\pi}$ & $\begin{array}{l}0 \\
\frac{0}{\pi} \\
\\
\vdots \\
2\end{array}$ \\
\hline INTD & 0.068 & 0.015 & 4.46 & $0.000 * * *$ & 0.068 & 0.153 & 4.44 & $0.000 * * *$ \\
\hline EDUC & 0.012 & 0.007 & 1.80 & $0.072^{*}$ & 0.010 & 0.007 & 1.40 & 0.163 \\
\hline BSIZE & -0.035 & 0.016 & -2.19 & $0.028^{* *}$ & -0.033 & 0.161 & -2.04 & $0.041^{*}$ \\
\hline BINDE & -0.011 & 0.008 & -1.42 & 0.155 & -0.011 & 0.008 & -1.44 & 0.150 \\
\hline CONC & -0.031 & 0.145 & -2.19 & $0.029^{* *}$ & -0.038 & 0.145 & -2.28 & $0.023^{* *}$ \\
\hline INTD*CONC & - & - & - & - & -0.018 & 0.007 & -2.39 & $0.017^{* *}$ \\
\hline $\mathrm{EDUC}^{*} \mathrm{CONC}$ & - & - & - & - & 0.010 & 0.126 & 0.84 & 0.400 \\
\hline $\mathrm{BSIZE}^{*} \mathrm{CONC}$ & - & - & - & - & 0.007 & 0.012 & 0.61 & 0.540 \\
\hline $\mathrm{BINDE}^{*} \mathrm{CONC}$ & - & - & - & - & -0.007 & 0.007 & -0.88 & 0.379 \\
\hline FSIZE & 0.053 & 0.004 & 12.30 & $0.000^{* * *}$ & 0.052 & 0.004 & 11.79 & $0.000^{* * *}$ \\
\hline LEVE & -0.031 & 0.257 & -1.22 & 0.223 & -0.032 & 0.025 & -1.25 & 0.210 \\
\hline FAGE & 0.003 & 0.000 & 7.50 & $0.000 * * *$ & 0.003 & 0.000 & 7.47 & $0.000^{* * *}$ \\
\hline Wald chi ${ }^{2}$ & 327.92 & & & & 340.14 & & & \\
\hline Prob $>$ chi $^{2}$ & 0.000 & & & & 0.000 & & & \\
\hline
\end{tabular}

Notes : ${ }^{*}=$ significant at $10 \%,{ }^{* *}=$ significant at $5 \%$ and ${ }^{* *}=$ significant at $1 \%$.

The same argument is proposed by (Cheng \& Leung, 2012b). BSIZE and SPECLST_MS is another relationship analysed on Table 3.4. There is significant negative relationship between BSIZE and SPECLST_MS. The finding from the analysis explains that an inverse relationship present between BSIZE and SPECLST_MS. This reflects that an increase in BSIZE might leads to decrease in client demand for SPECLST-MS at rate of 0.035 with P-value of $(0.028)$ at $5 \%$ level of significant, this infer that the more directors occupy corporate board, the lower will be the clients demand for SPECLST_MS, The same argument is reported by Abbott, Parker, and Peters (2004) report that small board of directors experience a lower incidence of restatements as they work to effective communication and there is less probability of a communication failure. This propose that when directors communicate effectively, they mitigate the incidence of confusion and then reduce errors, consequently they are more sensitive to the issues that could influence their investors and shareholders confidence, specifically concerning financial reporting issues. The influence of BINDE is not significant (Table 3.4). Its influence is about -0.11 for SPECLST_MS. The implication of this findings that for every increase in board member independence by one unite, SPECLST_MS would rise by 0.11 . The result of this study align with that of Karaibrahimoglu (2013) that there in adverse relationship between BINDE and SPECLST_MS as a result of substitution influence between the two variables. The moderating influence of wedge with INTD on SPECLST_MS is inverse and significant. Thereby showing not only a fall on all the impact from $0.68 \%$ to $0.18 \%$ but also a fall in SPECLST_MS for every increase in INTD. Past researches by Fan and Wong (2002) and Park and Shin (2004) have supported the outcome of the moderating effects of concentrated ownership on INTD. This demonstrates the substitution impact between corporate governance and audit quality in the presence of high concentrated ownership. There is an insignificant moderating impact of EDUC on SPECLST_MS as opposed to a significant relationship as a result of the moderating influence reducing the impact on SPECLST_MS from 0.12 to 0.10 . This result is being supported by previous study $\mathrm{Wu}$, Chen, and Lee (2016) that CONC positively influence on the relationship between corporate governance and earning management. Thus, this undermine client incentive and ability to demand high audit quality. This conclusion is consistent with that of previous studies (González \& García-Meca, 2014; La Porta, Lopez-de-Silanes, Shleifer, \& Vishny, 1999). BSIZE has a positive but insignificant moderating influence on SPECLST_MS. Compared to previous analysis, this influence was negative and insignificant as well. However, in terms of its effect it fell from $0.35 \%$ to $0.07 \%$. The outcome of this analysis has never been supported by any study whatsoever. Family ownership with high CONC have strong incentive to increase their interests at the expenses of minority shareholders as a result of their ability to monitor management directly instead of external monitoring mechanism (Claessens, 
Djankov, Fan, \& Lang, 2002). Then, this issue block corporate governance effectiveness and efficiency that effect negatively to reduce clients incentive to demand high quality audit. The moderating impact of BINDE is insignificant and negative. The effects are negative in both instances. The important feature however, is that the effects on SPECLST_MS has reduced from 0.011 to 0.007 . The same opinion is proposed by Wu et al. (2016) that independent directors impact positively client incentive to involve with earning manipulation in the presence of high concentrated ownership. Consequently, they are less likely to hire strong monitoring mechanism. The results of control variables (Table 3.4) shows that FSIZE, LEVE and FAGE have significant relationship with firm performance. To sum up, the study results show that board characteristics (e.g. INTD, EDUC and BSIZE) increase client incentive and ability to demand SPECLST_MS. While, this relationship is weaken in the presence of high CONC in the environment of Turkey.

\section{Conclusion}

This study investigates the relationship between INTD, EDUC, BSIZE and BINE and SPECLST_MS of public listed companies in BIST. In order to answer this study questions, this study employ cross-sectional time-series FGLS regression to controls of the issues of Autocorrelation and heteroscedasticity on a sample of 146 listed Turkish firms. This study demonstrations that there is a relationship between board characteristics and high quality audit measured by SPECLST_MS. The results seem to suggest that greater concentration need to be taken by firms to have more INTD, EDUC, and small BSIZE which is argued and found in this study to have significant implication on clients incentive and ability to demand high quality audit. Nevertheless, the result finds weak relationship between board characteristics and audit quality in the presence of CONC. The research thus, recommends that policy makers encourage listed firms to make their boards with various attitudes of directors and issue new regulation. Those regulations should be more appropriate for family firms with high concentrated ownership. The study also recommends further investigations that will include more data, inclusion of other characteristics of directors both before and after the regulatory changes of 2012 for comparison of clients demand before and the amendments.

\section{References}

1. Abbott, L. J., Parker, S., \& Peters, G. F. (2004) Audit committee characteristics and restatements. Auditing : A Journal of Practice \& Theory, 23(1), 69-87.

2. Adams, R. B., \& Ferreira, D. (2009). Women in the boardroom and their impact on governance and performance. Journal of Financial Economics, 94(2), 291309 .

3. Adams, R. B., Gray, S., \& Nowland, J. (2010). Is there a business case for female directors? Evidence from the market reaction to all new director appointments. In 23rd Australasian Finance and Banking Conference.

4. Aguilera, R. V, Filatotchev, I., Gospel, H., \& Jackson, G. (2008). Contingencies, complementarities, and costs in corporate governance models. Organization Science, 19(3), 475-492.

5. Aguilera, R. V, \& Jackson, G. (2003). The crossnational diversity of corporate governance : Dimensions and determinants. Academy of Management Review, 28(3), 447-465.

6. Ararat, M., Aksu, M., \& Tansel Cetin, A. (2015). How board diversity affects firm performance in emerging markets : Evidence on channels in controlled firms. Corporate Governance (Oxford), 23(2), 83-103. http :// doi.org/10.1111/corg.12103

7. Ararat, M., Süel, E., Aytekin, B., \& Alkan, S. (2014). Women on board Turkey : 2014 (2nd Annual Report : Independent Women Directors Project).

8. Bantel, K. A., \& Jackson, S. E. (1989). Top management and innovations in banking : Does the composition of the top team make a difference? Strategic Management Journal, 10(S1), 107-124.

9. Beiner, S., Drobetz, W., Schmid, F., \& Zimmermann, H. (2004). Is board size an independent corporate governance mechanism? Kyklos, 57(3), 327356.

10. Bohinc, R., \& Bainbridge, S. M. (2001). Corporate governance in post-privatized Slovenia. The American Journal of Comparative Law, 49(1), 49-77.

11. Carcello, J. V, Hermanson, D. R., Neal, T. L., \& Riley, R. A. (2002). Board Characteristics and Audit Fees*. Contemporary Accounting Research, 19(3), 365-384.

12. Chancharat, N., Krishnamurti, C., \& Tian, G. (2012). Board structure and survival of new economy IPO firms. Corporate Governance : An International Review, 20(2), 144-163.

13. Cheng, L. T. W., \& Leung, T. Y. (2012a). The Effects of Management Demography on Auditor Choice and Earnings Quality : Evidence from China. Review of Pacific Basin Financial Markets and Policies, 15(02), 1150009. http ://doi.org/10.1142/S0219091511500093

14. Cheng, L. T. W., \& Leung, T. Y. (2012b). The Effects of Management Demography on Auditor Choice and Earnings Quality : Evidence from China. Review of Pacific Basin Financial Markets and Policies, 15(02), 1150009. http ://doi.org/10.1142/S0219091511500093

15. Claessens, S., Djankov, S., Fan, J. P. H., \& Lang, L. H. P. (2002). Disentangling the incentive and entrenchment effects of large shareholdings. The Journal of Finance, 57(6), 2741-2771.

16. Courtney, N. P., \& Jubb, C. A. (2005). . Attachments between directors and auditors : do they affect engagement tenure? ANU E Press Canberra.

17. Craswell, A. T., Francis, J. R., \& Taylor, S. L. 
(1995). Auditor brand name reputations and industry specializations. Journal of Accounting and Economics, 20(3), 297-322.

18. Dalton, D. R., Daily, C. M., Johnson, J. L., \& Ellstrand, A. E. (1999). Number of directors and financial performance : A meta-analysis. Academy of Management Journal, 42(6), 674-686.

19. Dalton, D. R., Hitt, M. A., Certo, S. T., \& Dalton, C. M. (2007). 1 The Fundamental Agency Problem and Its Mitigation : Independence, Equity, and the Market for Corporate Control. The Academy of Management Annals, 1(1), 1-64.

20. Datta, D. K., \& Rajagopalan, N. (1998). Industry structure and CEO characteristics : An empirical study of succession events. Strategic Management Journal, 833852

21. Davies, P. L. (2000). Board structure in the UK and Germany : convergence or continuing divergence?

22. Davison, A. G., Stening, B. W., \& Wai, W. T. (1984). Auditor concentration and the impact of interlocking directorates. Journal of Accounting Research, 313-317.

23. Desender, K., Aguilera, R. V, Crespi-Cladera, R., \& Garcia-Cestona, M. A. (2009). Board characteristics and audit fees : Why ownership structure matters. University of Illinois at Urbana-Champaign, College of Business WP, 9-107.

24. Deutsch, Y. (2005). The impact of board composition on firms' critical decisions : A meta-analytic review. Journal of Management, 31(3), 424-444.

25. Fama, E. F., \& Jensen, M. C. (1983). Separation of ownership and control. Journal of Law and Economics, 301-325.

26. Fan, J. P. H., \& Wong, T. J. (2002). Corporate ownership structure and the informativeness of accounting earnings in East Asia. Journal of Accounting and Economics, 33(3), 401-425.

27. Filatotchev, I., Lien, Y.-C., \& Piesse, J. (2005). Corporate governance and performance in publicly listed, family-controlled firms : Evidence from Taiwan. Asia Pacific Journal of Management, 22(3), 257-283.

28. Finkelstein, S., \& Hambrick, D. C. (1996a). Strategic leadership : Top executives and their effects on organizations. South-Western Pub.

29. Finkelstein, S., \& Hambrick, D. C. (1996b). Strategic Leadership : Top Executives And Their Effects On Organizations (Hornbooks) Author : Sydney Finkelstein, Donald C. (Vol. 22). South-Western Pub.

30. Gacar, A. (2016). Relationship Between Audit Quality and Corporate Governance : An Empirical Research in Borsa Istanbul. IOSR Journal of Business and Management (IOSR-JBM), 18(11), 84-88. http ://doi.org/10.9790/487X-1811068488

31. González, J. S., \& García-Meca, E. (2014). Does corporate governance influence earnings management in
Latin American markets? Journal of Business Ethics, 121(3), 419-440.

32. Greene. (2003). Econometric Analysis of Count Data. Journal of the American Statistical Association (Vol. 97). http :// doi.org/10.1198/jasa.2002.s458

33. Guest, P. M. (2009). The impact of board size on firm performance : evidence from the UK. The European Journal of Finance, 15(4), 385-404.

34. Hair, J. F. J., Black, W. C., Babin, B. J., \& Anderson, R. E. (2010). Multivariate Data Analysis Seventh Edition Prentice Hall.

35. Haniffa, R., \& Hudaib, M. (2006). Corporate Governance Structure and Performance of Malaysian Listed Companies. Journal of Business Finance \& Accounting, 33(7-8), 1034-1062. http ://doi.org/10.1111/j.1468-5957.2006.00594.x

36. Harris, I. C., \& Shimizu, K. (2004). Too busy to serve? An examination of the influence of overboarded directors. Journal of Management Studies, 41(5), 775-798. 37. Hashim, H. A., \& Rahman, M. S. A. (2011). Multiple board appointments : are directors effective? International Journal of Business and Social Science, 2(17).

38. Hay, D. C., Knechel, W. R., \& Wong, N. (2006). Audit fees : A Meta-analysis of the effect of supply and demand attributes. Contemporary Accounting Research, 23(1), 141-191.

39. Hillman, A., Cannella, A. J., \& Paetzold, R. (2000). The resource dependence role of corporate directors : strategic adaptation of board composition in response to environmental change. Journal of Management ..., 37(March), 235-256. http :// doi.org/DOI : 10.1111/1467-6486.00179

40. Jensen, M. C. (1993). The modern industrial revolution, exit, and the failure of internal control systems. The Journal of Finance, 48(3), 831-880.

41. Jensen, M. C., \& Meckling, W. H. (1979). Theory of the firm : Managerial behavior, agency costs, and ownership structure. Springer.

42. Kaplan, S. N., \& Minton, B. A. (1994). Appointments of outsiders to Japanese boards : Determinants and implications for managers. Journal of Financial Economics, 36(2), 225-258.

43. Karaibrahimoglu, Y. Z. (2013). Is Corporate Governance A Determinant of Auditor Choice. Ege Academic Review, 13(2), 273-284.

44. Kosnik, R. D. (1987). Greenmail : A study of board performance in corporate governance. Administrative Science Quarterly, 163-185.

45. La Porta, R., Lopez-de-Silanes, F., Shleifer, A., \& Vishny, R. (1999). The quality of government. Journal of Law, Economics, and Organization, 15(1), 222-279.

46. Lee, H. Y., Mande, V., \& Ortman, R. (2004). The effect of audit committee and board of director independence on auditor resignation. Auditing : A 
Journal of Practice \& Theory, 23(2), 131-146.

47. Maury, B. (2006). Corporate performance, corporate governance and top executive turnover in Finland. European Financial Management, 12(2), 221248.

48. Mustafa, A., Che-Ahmad, A., Chandren, \& Sitraselvi. (2017). Board diversity and audit quality : Evidence from Turkey. Journal of Advanced Research in Business and Management Studies, 6(1), 50-60.

49. Nugroho, B. Y., \& Eko, P. U. (2012). Board characteristics and earning management. BISNIS \& BIROKRASI : Jurnal Ilmu Administrasi Dan Organisasi, 18(1).

50. Ou-Yan, H., \& Shuang-shii, C. (2007). CEO turnover, board chairman turnover, the key determinants : Empirical study on Taiwan listed company. The Business Review, 7(2), 129-135.

51. Park, Y. W., \& Shin, H.-H. (2004). Board composition and earnings management in Canada. Journal of Corporate Finance, 10(3), 431-457.

52. Peasnell, K. V, Pope, P. F., \& Young, S. (2005).

Board monitoring and earnings management : Do outside directors influence abnormal accruals? Journal of Business Finance \& Accounting, 32(7-8), 1311-1346.

53. Plian, P. H. (1995). Human capital or social networks : What constrains CEO dismissals? In Academy of Management Proceedings (Vol. 1995, pp. 37-41). Academy of Management.

54. Rediker, K. J., \& Seth, A. (1995). Boards of directors and substitution effects of alternative governance mechanisms. Strategic Management Journal, 16(2), 85-99.

55. Seabright, M. a., Levinthal, D. a., \& Fichman, M. (1992). Role of Individual Attachments in the Dissolution of Interorganizational Relationships. Academy of Management Journal, 35(1), 122-160. http ://doi.org/10.2307/256475

56. Shleifer, A., \& Vishny, R. W. (1997). A survey of corporate governance. The Journal of Finance, 52(2), 737783.

57. Sundaramurthy, C. (1996). Corporate governance within the context of antitakeover provisions. Strategic Management Journal, 377-394.

58. Tuggle, C. S., Sirmon, D. G., Reutzel, C. R., \& Bierman, L. (2010). Commanding board of director attention : investigating how organizational performance and CEO duality affect board members' attention to monitoring. Strategic Management Journal, 31(9), 946968.

59. Watts, R. L., \& Zimmerman, J. L. (1990). Positive accounting theory : a ten year perspective. Accounting Review, 131-156.

60. Wooldridge. J. M. (2002). Econometric Analysis ofCross Section arrd Panel Data (2nd ed.). Massachusetts Institute of Technology.
61. $\mathrm{Wu}, \quad$ S., Chen, C.-M., \& Lee, P.-C. (2016). Independent directors and earnings management : The moderating effects of controlling shareholders and the divergence of cash-flow and control rights. The North American Journal of Economics and Finance, 35, 153-165. 62. Zaman, M., Hudaib, M., \& Haniffa, R. (2011). Corporate Governance Quality, Audit Fees and NonAudit Services Fees. Journal of Business Finance \& Accounting, 38(1-2), 165-197. 